\title{
“TOOL IN THE R2P TOOLBOX”? ANALYSING THE ROLE OF THE INTERNATIONAL CRIMINAL COURT IN THE THREE PILLARS OF THE RESPONSIBILITY TO PROTECT
}

\begin{abstract}
In the last two decades, two important instruments emerged to combat mass atrocities. In 2002 the International Criminal Court (ICC) was established. Subsequently, in 2005, the international community politically committed itself to the responsibility to protect populations from mass atrocities (R2P) distinguishing three pillars: (i) the responsibility of the state to protect its own population, (ii) the responsibility to help states live up to this responsibility and (iii) the responsibility of the international community to intervene when states manifestly fail to protect their population. While the ICC is frequently referred to as a "tool in the R2P toolbox," an analysis of the ways in which the ICC works within R2P's pillar structure was missing. Using the R2P pillar-structure, this article systematically analyses how the ICC plays a role in the implementation of R2P. More specifically, this paper disentangles the diverse modalities of ICC engagement with states - such as ratification of its Statute, positive complementarity, opening of preliminary examinations or investigations - and demonstrates the complex dynamics of the interaction between the implementation of R2P and the actions of the ICC. The workings of the Court create fluid dynamics that shift back and forth between the different pillars at different points in time. In addition, the ICC can contribute to different pillars at the same time. In some instances, however, it fits uncomfortably in the R2P pillar structure, necessitating the conceptualisation of a pillar two and a half.
\end{abstract}

"The Court should be seen as a tool in the R2P toolbox - strengthening the correlation and the interaction between both is what I think we should be concerned more with in order to maximise effectively the protection which we will give to civilians."

* Maartje Weerdesteijn, VU University Amsterdam. E-mail: m.weerdesteijn@vu.nl ** Barbora Holá, Netherlands Institute for the Study of Crime and Law Enforcement (NSCR). E-mail: bhola@nscr.nl.

${ }^{1}$ Fatou Bensouda, The Prosecutor of the ICC, as cited in K. Ainley, 'The Responsibility to Protect and the International Criminal Court: counteracting the crisis,' (2015) 91(1) International Affairs 37, p. 44. 
"All of us who are concerned for peace and triumph of reason and justice must be keenly aware how small an influence reason and honest good will exert upon events in the political field." 2

\section{INTRODUCTION}

In the last two decades, two important instruments emerged to combat mass atrocities. In 2002 the International Criminal Court (ICC) was established and subsequently, in 2005, the international community politically committed itself to the responsibility to protect (R2P); the responsibility to protect populations from mass atrocities. The ICC is a permanent court that seeks to hold individuals accountable for genocide, crimes against humanity and war crimes ${ }^{3}$ if states fail to do so. As such, it is a complementary court, only able to prosecute if the competent state is unable or unwilling to do so. It has jurisdiction if a state signs and ratifies its founding document, the Rome Statute, if a state declares it accepts the jurisdiction of the court in relation to a crime, or if the UN Security Council (UNSC) refers a situation to the Court. The responsibility to protect functions in a similar, complementary manner, with the primary responsibility to protect individuals against mass atrocities resting with domestic states. Only if the domestic state fails to protect, does the responsibility shift to the international community, which is then prepared to intervene, through the UN Security Council. This division of labour has been conceptualised as a three-pillar structure. The first pillar entails the responsibility of the state to protect its own population, the second pillar is the responsibility to help states live up to this responsibility and the third pillar revolves around the responsibility of the international community to intervene when states manifestly fail to protect their population. ${ }^{4}$

\footnotetext{
${ }^{2}$ A. Einstein, Ideas and Opinions (New York: Crown Publishers 1954, 1982).

${ }^{3}$ As will be explained further below, we will refer to these crimes as mass atrocity crimes. The ICC may also exercise jurisdiction over the crime of aggression but to date has not done so. The definition over the crime of aggression was agreed upon in 2010, it was activated in 2017 and the court has had jurisdiction from 17 July 2018 onwards.

${ }^{4}$ B. Ki-Moon, Implementing the Responsibility to Protect. Report of the Secretary General (2009) A/63/677.
} 
The two institutions - a term we use to refer to R2P as a political norm as well as the ICC as a formal organization ${ }^{5}$ - are supposed to be complementary and work in tandem to prevent and stop the perpetration of the most horrendous crimes. The court is more or less regularly referred to as a "tool in the toolbox" of R2P, ${ }^{6}$ even by the ICC Prosecutor herself, ${ }^{7}$ but it is not clear how, or the extent to which, the tool works within R2P's pillar structure. This is firstly because the relationship is innately complicated and the two institutions differ in fundamental ways; one is a court of law ideally defined by purported impartiality, rigidity and strict rules, and the other a political agreement that embraces pragmatism and flexibility. While both institutions, therefore, aim to combat mass atrocity crimes, it is not obvious that they are inherently complementary and scholars have debated whether the two are better off not being associated with each other. ${ }^{8}$ Secondly, most of the scholarly literature discusses how the ICC and R2P interact in general, across all three pillars of R2P, ${ }^{9}$ or focus (predominantly) on the most controversial third pillar. ${ }^{10}$ In

${ }^{5}$ This is in line with the sociological definition of what constitutes an institution. According to Rojas, it is common to see institutions as "stable patterns of behavior that define, govern, and constrain action" but an institution may likewise refer to an "organization or other formal social structure that governs a field of action." F. Rojas, 'Institutions,' http:/www.oxfordbibliographies.com/view/document/obo9780199756384/obo-9780199756384-0132.xml Accessed 12 July 2019. The sociological definition, therefore, covers political norms, such as R2P, that define acceptable be haviour and as such form a constraint on the behaviour of states. At the same time, it also captures more formal organizational structures, such as the ICC.

${ }^{6}$ B. Ki-Moon, supra note 4, p. 12.

${ }^{7}$ F. Bensouda 'The Role of the International Criminal Court Under the Framework of the R2P' (2012). Accessed 09 January 2019, https://www.sam-network.org/ video/the-role-of-the-international-criminal-court-under-the-framework-of-the-re sponsibility-to-protect.

${ }^{8}$ C. Stahn, 'Marital Stress or Grounds for Divorce? Rethinking the Relationship Between R2P and International Criminal Justice' Criminal Law Forum (2015) 26(13), 13; A.J. Bellamy 'Responsibility to Protect: Justice and Responsibility - Related but Not Synonymous' in: J. Waterlow, J. Schuhmacher (Eds.), War Crimes Trials and Investigations (Cham: Palgrave Macmillan, 2018) 263.

${ }^{9}$ K. Ainley, supra note 1; D. Chandler, 'Born Posthumously: Rethinking the Shared Characteristics of the ICC and R2P' Finnish Yearbook of International Law (2010) 21, 1; B.N. Schiff, 'Can the International Criminal Court contribute to the Responsibility to Protect' International Relations (2016) 1; Stahn, supra note 8.

${ }^{10}$ K. Mills, 'R2P and the ICC: At Odds or in Sync?' Criminal Law Forum (2015) 26, 73; A. Hehir and A. Lang, 'The Impact of the Security Council on the Efficacy of the International Criminal Court and the Responsibility to Protect' Criminal Law Forum (2015) 26, 153. 
doing so, the diverse nature of the pillars, and of the corresponding responsibilities they might generate, gets obfuscated. Finally, no one has dissected the workings of the ICC and systematically assessed and compared diverse modalities of ICC engagement in (potential) situations of atrocity crimes, depending for example on the different ways the ICC jurisdiction can be triggered. This is unfortunate since the role of the ICC and its impact, for better or worse, on the implementation of $\mathrm{R} 2 \mathrm{P}$ is not necessarily equal across the pillars, and across the different manners in which the Court can act according to its Statute. This paper will, therefore, disentangle both the R2P and the ICC, and will systematically analyse the role of the diverse modalities of ICC engagement under each of the three pillars. It, therefore, seeks to investigate to what extent and how the ICC can play a role in the implementation of the three pillars of the Responsibility to Protect.

In order to answer this question, the article will first briefly discuss the evolution of R2P and explain what each of the pillars entails. Thereafter, it will analyse the relationship between the ICC and R2P, firstly setting out their similarities, differences and challenges when it comes to preventing and stopping atrocities, before delving into a discussion of each of the pillars, and different modalities of ICC engagement in atrocity crimes situations. In doing so, we discuss the empirical scholarship that sheds light on the extent to which the ICC helps or hampers the protection of populations and we use various situations at the ICC as examples, including Uganda, DRC, Guinea, Venezuela, Kenya, Afghanistan, Libya and Darfur. We conclude by arguing that the workings of the Court fit rather uncomfortably in the three-pillar structure of R2P, necessitating the conceptualization of what we call a pillar two and a half. In addition, the relationship is actually a fluid one, and the interaction between the ICC and R2P in a given situation is hardly ever confined to one particular pillar, but shifts between different pillars at different moments in time.

\section{THE EVOLUTION OF THE RESPONSIBILITY TO PROTECT}

After its inaction during the genocide in Rwanda, and NATO's unlawful intervention in Kosovo, the international community was torn. There was an outcry over the failure to stop the genocide and outrage over the total disregard of the UN Security Council and international law when NATO intervened in Kosovo. It led Kofi Annan, the Secretary General of the UN at the time, to ask the General Assembly "If humanitarian intervention is indeed an unac- 
ceptable assault on sovereignty, how should we respond to a Rwanda, to a Srebrenica - to gross and systematic violations of human rights that offend every precept of our common humanity.",11 As such, the responsibility to protect was originally developed to find a solution to the international disagreement about the extent to which humanitarian intervention was needed and justifiable.

It was the Canadian government that took the lead in the search for a solution to the dilemma which humanitarian intervention posed. It brought together a panel of experts who travelled the world to find consensus on whether mass atrocities should be stopped, if need be through humanitarian intervention, or whether this would pose an unacceptable infringement on a state's sovereignty. They published a report that reconceptualised state sovereignty as responsibility. At its core was the understanding that countries had the responsibility to protect their populations from mass atrocities and when they failed, this responsibility was transferred to the international community. Its scope covered "human security" and included the responsibility to prevent, react, and rebuild. ${ }^{12} \mathrm{R} 2 \mathrm{P}$ was controversial, on the one hand, because there were fears it would function as a way for the powerful countries to intervene in the affairs of less powerful states and on the other, because powerful states were afraid it would obligate them to act. ${ }^{13}$

The controversies nothwithstanding, R2P was endorsed, albeit in a much more limited form, at the World Summit in 2005. The scope of the responsibility to protect was restricted to genocide, crimes against humanity, war crimes and ethnic cleansing. In addition, the responsibility to rebuild a society after these atrocities were perpetrated was removed. In a subsequent report the Secretary General delineated three pillars that underlie the new responsibility to protect. ${ }^{14}$ The first pillar entails the responsibility of states to protect their populations from the aforementioned atrocity crimes. The second pillar details the responsibility of states to help other states to protect their populations. The third pillar includes a timely and decisive response based

${ }^{11}$ K. Annan, K. "We the Peoples" The Role of the United Nations in the 21st Century.' (New York: United Nations 2000).

${ }^{12}$ International Commission on Intervention and State Sovereignty, The Responsibility to Protect (Ottawa: The International Development Research Center, 2001).

${ }^{13}$ C. Stahn, 'The Responsibility to Protect: Political Rhetoric or Emerging Legal Norm?' The American Journal of International Law, 101(1) (2007), 99, pp. 119-120.

${ }^{14}$ B. Ki-Moon, supra note 4. 
on the preparedness that was voiced by states at the World Summit to react through the UN Security Council, if need be through Chapter VII, when atrocity crimes are perpetrated. ${ }^{15}$

With the new pillar structure, R2P was less focussed on military action to stop atrocity crimes, which became just a small part of the third pillar. In addition, with its scope being limited to the same international core crimes the ICC has jurisdiction over, international criminal justice came to be seen as potentially an important mechanism to implement R2P across the three pillars, as explained in the next three paragraphs.

\subsection{The First Pillar}

In his annual report, UN Secretary General at the time, Ban Ki Moon, defined the first pillar of R2P as follows:

Pillar one is the enduring responsibility of the State to protect its populations, whether nationals or not, from genocide, war crimes, ethnic cleansing and crimes against humanity, and from their incitement. ${ }^{16}$

As such, the state is "the bedrock" of R2P. ${ }^{17}$ The report encompassed a wide variety of recommendations, including that states should become party to the Rome Statute in order to implement the first pillar. In 2013, the Secretary General, in his yearly report on R2P, reflected on how the first pillar could be implemented to prevent mass atrocities. He stressed again that "[r]esilience implies developing appropriate legal frameworks and building State structures and institutions that are legitimate, respect international human rights law, and the rule of law in general and that have the capacity to address and defuse sources of tension before they escalate." ${ }^{\prime 18}$ Two years later the report added that in order to advance the implementation of the first pillar, the participation of states in "key legal instruments" should be promoted. ${ }^{19}$ The Secretary General emphasised that more needed to be done in the sphere of international criminal justice because so

\footnotetext{
${ }^{15} 2005$ World Summit Outcome Document (WSOD), GA Res. 60/1, paras. 138139.

${ }^{16}$ B. Ki-Moon, supra note 4, p. 8.

${ }^{17}$ Ibid., p. 10.

${ }^{18}$ B. Ki-Moon, Responsibility to Protect: State Responsibility and Prevention. Report of the Secretary General (2013) A/67/929, p. 2.

${ }^{19}$ B. Ki-Moon, A Vital and Enduring Commitment: Implementing the Responsibility to Protect. Report of the Secretary General (2015), p. 7.
} 
many countries still were not parties to the Rome Statute and those who were too often forsake their obligations under the Statute. In addition, more needed to be done to remove the differences between the manner in which international and domestic jurisdictions investigate and sanction atrocity crimes. He concludes that "[e]nding impunity is neither optional nor negotiable. Accountability not only contributes to preventing the recurrence of atrocity crimes but also makes national institutions stronger and more legitimate.,"20

\subsection{The Second Pillar}

According to Ban Ki Moon, pillar two "is the commitment of the international community to assist States in meeting those [pillar one] obligations." 21 The Secretary General then proceeded to delineate four dimensions, encouraging states to live up to their responsibility to protect, helping them to exercise it, helping them to build the capacity to do so and assisting states under stress of conflict breaking out. The second pillar thus imposes the responsibility to help states implement the first pillar and prevent atrocity crimes. In practice, this prevention also encompasses efforts to prevent the recurrence of atrocities, and the prevention of further atrocities. The first two pillars of the responsibility to protect, therefore, also extend to the phase when crises are already ongoing and when efforts are mainly targeted to prevent renewed atrocities. The Secretary General in this sense sees the responsibility that stems from the second pillar to include assistance in "building capacities that will make [states] more resilient to the risk factors of atrocity crimes; and add to their protection capabilities in situations of emerging or ongoing crises.",

A concern that is raised in light of pillar two is that often the government might be implicated in the perpetration of atrocities and it has been argued that assistance in those circumstances would be unacceptable. ${ }^{23}$ The Secretary General emphasised, in this respect, that the second pillar mostly comes into play with weak and divided

\footnotetext{
${ }^{20}$ Ibid., p. 8.

${ }^{21}$ B. Ki-Moon, supra note 4, p. 9.

${ }^{22}$ B. Ki-Moon, Fulfilling our collective responsibility: international assistance and the responsibility to protect. Report of the Secretary General (2014) A/68/947, p. 3.

${ }^{23}$ A. Gallagher, 'The Promise of Pillar II: Analysing International Assistance under the Responsibility to Protect' International Affairs 91(6) (2015), 1259, p. 1267.
} 
states that do not have the means to protect their population but are willing to do so. ${ }^{24}$ Consent of the domestic state is at the heart of the second pillar. ${ }^{25}$ Gallagher finds, therefore, Pillar II might be particularly useful for addressing threats posed by non-state armed groups. $^{26}$

In 2014 the annual report of the Secretary General was devoted in its entirety to the implementation of the second pillar. ${ }^{27}$ The report explicitly mentions the ICC as an important actor that seeks to provide states with assistance to meet their responsibility to protect:

The International Criminal Court and the principle of positive complementarity established by the Rome Statute and other international criminal accountability mechanisms also aim to assist States in protecting their populations by sharing information, training national prosecutors and investigators and combating the impunity that facilitates atrocity crimes. ${ }^{28}$ It attests to the high hopes and expectations that are present within the UN as to the capability and impact of the Court.

\subsection{The Third Pillar}

Ban Ki Moon conceptualised the third pillar to mean "the responsibility of Member States to respond collectively in a timely and decisive manner when a State is manifestly failing to provide such protection." 29 The exact wording in the World Summit Outcome Document demonstrates such a response should always flow through the UN:

The international community, through the United Nations, also has the responsibility to use appropriate diplomatic, humanitarian and other peaceful means, in accordance with Chapters VI and VIII of the Charter, to help protect populations from genocide, war crimes, ethnic cleansing and crimes against humanity. In this context, we are prepared to take collective action, in a timely and decisive manner, through the Security Council, in accordance with the Charter, including Chapter VII, on a case-by-case basis and in cooperation with relevant regional organizations as appropriate, should peaceful means be

\footnotetext{
${ }^{24}$ B. Ki-Moon, supra note 4, p. 15.

${ }^{25}$ A. Gallagher, supra note 23, p. 1264.

${ }^{26}$ A. Gallagher, supra note 23.

${ }^{27}$ B. Ki-Moon, supra note 22.

${ }^{28}$ Ibid., p. 6.

${ }^{29}$ B. Ki-Moon, supra note 4, p. 9.
} 
inadequate and national authorities manifestly fail to protect their populations. $^{30}$

Importantly, the Secretary General here too finds that the ICC has an important role to play and suggests that states need to be reminded that they can be referred to the Court by the UN Security Council if they fail to live up to their responsibility to protect. ${ }^{31}$ In 2012 the annual report was exclusively focused on the third pillar. The ICC is again recognised as an important "tool" for the implementation of R2P:

The threat of referrals to ICC can undoubtedly serve a preventative purpose and the engagement of ICC in response to the alleged perpetration of crimes can contribute to the overall response. More generally the emergence of a system of international criminal justice has had a positive influence on the development of the concept of RtoP. ${ }^{32}$

The wording reflects the limitless optimism with which it regards the ICC and the impact it has on R2P and the development of conflicts.

\section{THE RELATIONSHIP BETWEEN R2P AND THE ICC}

The idea that the ICC and R2P are tied together in a collective effort to address mass atrocities has been, as explained above, repeatedly highlighted by the UN. According to UN Secretary General Ban Ki Moon "the International Criminal Court and the United Nationsassisted tribunals have added an essential tool for implementing the responsibility to protect, one that is already reinforcing efforts at dissuasion and deterrence." 33 The ICC Prosecutor has also highlighted the importance of the ICC for the implementation of R2P. She described the court as a "tool in the toolbox" in the implementation of R2P. ${ }^{34}$ The assertion that international criminal justice potentially can contribute to the implementation of R2P has been facilitated by the decision to narrow the scope of R2P to cover only what has become known as "(mass) atrocity crimes" meaning,

\footnotetext{
${ }^{30}$ WSOD, supra note 15 , para 139.

${ }^{31}$ B. Ki-Moon, supra note 4, p. 23.

${ }^{32}$ B. Ki-Moon, Responsibility to Protect: Timely and Decisive Response. Report of the Secretary General (2012) A/66/874, p. 9.

${ }^{33}$ B. Ki-Moon, supra note 4, p. 12.

${ }^{34} \mathrm{~F}$. Bensouda, supra note 7.
} 
genocide, crimes against humanity, war crimes and ethnic cleansing; the crimes that are also covered by Rome Statute. ${ }^{35}$ As such Scheffer argues atrocity crimes discourse

remains faithful to the requirements of international criminal law (particularly in the work of international and hybrid criminal tribunals and national criminal courts) and at the same time enables timely public discourse (by governments, activists, the media, scholars, and the general public)... ${ }^{36}$

Despite the optimism that was sparked by the World Summit of the potentialities of international criminal justice for the implementation of R2P, there are countless differences between the institutions that complicate them functioning harmoniously. They are a different kind of institution; one being a formal legal institution and the other a political norm. Even though the ICC cannot escape politics in order to function, it is first and foremost a legal court, an institution that functions in accordance with the letter of the law. It ideally values and does what is legally required, above what is politically expedient. ${ }^{37} \mathrm{R} 2 \mathrm{P}$ is grounded in law but it is, above else, a political norm and the responsibilities endowed in it transcend states' legal obligations. Therefore, while each aims to rid the world of atrocity crimes, the ways in which they seek to do so differ. R2P seeks the prevention of atrocity crimes and to protect populations at risk while the main purpose of the ICC is to punish those that have already perpetrated them. ${ }^{38}$

Because of these differences, many scholars question the extent to which the ICC and R2P are mutually reinforcing institutions. Some fear that its close association with R2P may politicize the Court. Mills argues, for instance, the ICC should be shielded from global politics as much as possible. ${ }^{39}$ Birdsall in a similar vein believes that the ICC

${ }^{35}$ All the mass atrocity crimes that are part of $\mathrm{R} 2 \mathrm{P}$ are covered by the Rome Statute but the act of ethnic cleansing is not criminalized per se but can be prosecuted as one of the other international crimes and the Rome Statute has the crime of aggression which is not covered by $\mathrm{R} 2 \mathrm{P}$.

${ }^{36}$ D. Scheffer, 'Atrocity Crimes Framing the Responsibility to Protect' Case Western Reserve Journal of International Law, 40(1) (2007), 111, p. 134.

${ }^{37} \mathrm{We}$ acknowledge, however, that the boundary between law and politics is oftentimes blurred and that in practice it is very difficult to disentangle the two. See e.g. A. Tiemessen 'The International Criminal Court and the politics of prosecutions' The International Journal of Human Rights 18(4) (2014) 444.

38 A.J. Bellamy, supra note 8, p. 272.

${ }^{39}$ K. Mills, supra note 10, p. 91. 
does not have much to gain from its association with $\mathrm{R} 2 \mathrm{P}$ because it is not capable of solving ongoing conflicts and it could risk becoming seen as a political tool. ${ }^{40}$ Other scholars are concerned that its close association with the ICC might be harmful to R2P as an international norm. Ralph points out "an ICC indictment of government leaders can link an R2P action to the concept of 'regime change', which, in the current political environment, complicates the task of maintaining the consensus that lends legitimacy to an intervention." 41 Schiff more generally is unconvinced that the ICC has anything to contribute to the implementation of $\mathrm{R} 2 \mathrm{P} .{ }^{42}$

Bellamy in this respect argues that trying to merge these institutions with their divergent approaches would risk making international criminal justice "selective and political without necessarily adding to the prevention of imminent atrocities" and that an effective implementation of $\mathrm{R} 2 \mathrm{P}$ may require decisions that are at odds with the legal logic of the ICC. ${ }^{43}$ In addition, R2P and the ICC differ in whom they hold accountable and what this accountability entails: The ICC is concerned with the criminal accountability of individuals, whereas R2P, as a political norm, holds states to account.

Problematising the functioning of both institutions is the partial reliance on the UN Security Council which they share. The UN Security Council is certainly not representative of the wider international community, and furthermore, the Council is inconsistent in its application of international law and norms. The inconsistency of the UNSC practice seems to tarnish the standing and legitimacy of both institutions and both seem to be in a state of existential crisis, making it more pertinent to analyse the workings between them. ${ }^{44}$

\section{THE ROLE OF THE ICC IN THE IMPLEMENTATION OF $\mathrm{R} 2 \mathrm{P}$}

While there is much debate as to whether the two institutions are complementary, not much is known about the role the ICC truly

\footnotetext{
${ }^{40}$ A. Birdsall, 'The Responsibility to Prosecute and the ICC: A Problematic Relationship?' Criminal Law Forum 26 (2015), 51, p. 52.

${ }^{41}$ J. Ralph, J. 'Symposium: International Criminal Justice and the Responsibility to Protect' Criminal Law Forum 26 (2015), 1, p. 3.

${ }^{42}$ B.N. Schiff, supra note 9.

${ }^{43}$ A. Bellamy, supra note 8, p. 264.

${ }^{44}$ E.g. A. Hehir and A. Lang, supra note 10; K. Ainley, supra note 1, pp. 39-41.
} 
plays in each of the pillars, beyond the hopeful remarks of the UN Secretary General and the Court's Prosecutor. Because R2P is composed of three unique pillars, each with their own problems and pitfalls, it is important to disentangle the concept and analyse the interactions of the Court and R2P under each pillar.

\subsection{The First Pillar: Ratifying the Rome Statute}

The first pillar constitutes the "bedrock" of R2P and places the primary responsibility on the State to protect its populations from mass atrocity crimes, among others, by developing appropriate legal frameworks and building institutions to address the crimes. In this sense, ratification of the ICC Statute is explicitly mentioned as one of the "means" States can employ to implement R2P. ${ }^{45}$ The argument goes that by ratifying the ICC Statute not only a necessary legal infrastructure to prosecute and punish individuals for atrocity crimes is put in place, which will strengthen the rule of law, but also that the incorporation of the norms of the Statute in the domestic legal frameworks will contribute to protecting populations from such crimes. ${ }^{46}$ In addition, according to an ICC official also the symbolic value, the moral and legal norms that are enforced, can contribute to the prevention of international crimes. ${ }^{47}$ Ratification of the Rome Statute is arguably one way to spread such norms.

At the time of writing, April 2020, 123 States are parties to the Rome Statute, and consequently have ratified the Statute. The existing empirical studies have indicated that countries which are more likely to ratify the Statute tend to be those where civilian populations are not regularly confronted with mass atrocity crimes such as established democracies with little internal violence and a

${ }^{45}$ B. Ki-Moon, $A$ vital and enduring commitment: implementing the responsibility to protect. Report of the Secretary General (2015) A/69/981, p. 7-8.

${ }^{46}$ B.N. Schiff, supra note 9, p. 5.

${ }^{47}$ Cited in D. Saxon, (2018). 'The International Criminal Court and the Prevention of Crimes' in: S.K. Sharma and J.M. Welsh (Eds.). The Responsibility to Prevent: Overcoming the Challenges of Atrocity Prevention (Oxford: Oxford University Press, 2018) 120, p. 120. 
strong rule of law. ${ }^{48}$ Additionally, not all these States have incorporated provisions of the Statute in their national laws. The latest academic estimates dating back to 2012 suggest that approximately $20-40 \%$ of these countries still need to adjust their national laws to the requirements of the Rome Statute when it comes either to the definition of the crimes, the modes of liability, or cooperation requirements as defined in the ICC Statute. ${ }^{49}$ Furthermore, the extent to which for example the exact ICC crimes definitions have been incorporated in domestic laws also largely varies across States. ${ }^{50}$ Therefore, a mere ratification of the Statute is a necessary but certainly not a sufficient step in creating the domestic legal framework for prosecuting atrocity crimes. There is some anecdotal evidence that countries may be adjusting policies to prevent the commission of atrocity crimes. Colombia, for instance, mentions the Rome Statute several times in their "Manual of Operational Law" of the armed forces. $^{51}$

Furthermore, even if the necessary legal framework and policies are in place, they need to be enforced in practice. In order to deter individuals from committing atrocities, and thus protect civilian populations from such crimes, (financial, political and human) resources need to be dedicated to creating the necessary institutions and capacities to enforce the existing laws and policies. As criminological

${ }^{48}$ T.L. Chapman, S. Chaudoin, 'Ratification Patterns and the International Criminal Court' International Studies Quarterly (2013) 57, 400; E.J. Powell, 'Two Courts Two Roads: Domestic Rule of Law and Legitimacy of International Courts' Foreign Policy Analysis 9(4) (2013), 349. However, also see B.A. Simmons, A.M. Danner 'Credible Commitments and the International Criminal Court' International Organization (2010) 64, pp. 225-256. They argue that ICC ratification patterns show evidence of credible commitments and autocracies, with recent history of violence, which are ready to resolve conflict and do not have strong accountability mechanisms, are more probable to ratify the ICC than democracies without any principled reasons to join the ICC, or autocracies with no recent violent past or strong domestic accountability mechanisms.

${ }^{49}$ E. Hunter 'Strengthening National Capacity to Prosecute Genocide, Crimes Against Humanity and War Crimes within the International Criminal Court System' in: J.C. Botero, R. Janse, S. Muller, C. Pratt (Eds.), Innovations in Rule of Law: A Compilation of Concise Essays (New York: HiiL innovating justice and World Justice Project, 2012), 29; G. Dancy, F. Montal 'From Law versus Politics to Law in Politics: A Pragmatist Assessment of the ICC's Impact' American University International Law Review 32(3) (2017), 645.

${ }^{50}$ J.B. Terracino 'National Implementation of ICC Crimes: Impact on National Jurisdictions and the ICC' Journal of International Criminal Justice 5(2) (2007) 421.

${ }^{51}$ D. Saxon, supra note 47, p. 129. 
literature has time and again demonstrated, it is the certainty of punishment (and probability of being apprehended) rather than its mere existence or severity, which seems to produce deterrent benefits. ${ }^{52}$ Oftentimes, however, the necessary financial and human resources to prosecute atrocities are lacking, in particular in countries undergoing transitions post-atrocities. In addition, the socio-political circumstances might not be very conducive to prosecuting atrocity crimes perpetrators and states potentially do so largely selectively, as some perpetrators can even be considered "heroes and patriots" rather than "criminals and wrongdoers" in their countries. ${ }^{53}$ Furthermore, when it comes to mass atrocity crimes, some scholars question whether perpetrators would be deterred by any threat of prosecution and punishment. In "extraordinary circumstances" of mass atrocities, individuals are not "rational" actors weighing costs of their potential prosecution and punishment against any potential benefits from committing atrocity crimes. ${ }^{54}$

Irrespective of these theoretical and pragmatic considerations, the emerging empirical scholarship has shown, however, that there might be broader positive effects of the ICC Statute ratification when it comes to protecting a civilian population from mass atrocities. Prorok for example has demonstrated that ratification of the ICC Statute significantly increases the likelihood of civil wars termination. ${ }^{55}$ Similarly, Simmons and Danner argue that especially in autocracies, with recent history of violence, which are ready to resolve conflict and do not have strong accountability mechanisms, ratification of the

${ }^{52}$ D. Nagin and G. Pogarsky 'Integrating Celerity, Impulsivity, and Extralegal Sanction Threats into a Model of General Deterrence: Theory and Evidence' Criminology 39(4), 2001, 865; M. Tonry 'The Functions of Sentencing and Sentencing Reform' 58 Stan.L.Rev. (2005), 37, p. 52.

${ }^{53}$ B. Hola, O. Simic 'ICTY Celebrities: War Criminal Coming Home' International Criminal Justice Review 28(4) (2018), 285.

${ }^{54}$ M.A. Drumbl Atrocity, Punishment and International Law (New York: Cambridge University Press, 2007).

${ }^{55}$ However, Prorok also identified an opposite effect of the ICC's preliminary examinations and investigations, i.e. the Court's more active involvement in a situation actually extends wars. For more discussion of these issues see below Sections 4.2.2 and 4.3.3. A.K. Prorok 'The (In)compatibility of Peace and Justice? The International Criminal Court and Civil Conflict Termination' International Organization 71(2) (2017), 213. 
Rome Statute actually facilitates peace. ${ }^{56}$ Jo and Simmons find that Rome-ratifying governments intentionally kill roughly 50\% fewer civilians than their non- ratifying or pre-ratification counterparts. ${ }^{57}$ Appel also demonstrated that governments from states that have ratified the Rome Statute commit lower levels of human rights abuses, such as torture, political imprisonment, extrajudicial killings, and disappearances, which often amount to mass atrocities. ${ }^{58}$ This is independent of State's prior human rights practices, trends over time, or other domestic conditions. ${ }^{59}$ On the other hand, some studies also demonstrate null or negative impact of ratifying the Rome Statute on the scale of human rights violations or peaceful resolution of (civil) wars in different situations. ${ }^{60}$

Despite some mixed results highlighting the importance of local contexts and histories, these studies taken together seem to indicate cautious optimism: States that have ratified the ICC Statute tend to

\footnotetext{
${ }^{56}$ B.A. Simmons, A.M. Danner, supra note 48.

${ }^{57}$ H. Jo, B.A. Simmons 'Can the International Criminal Court Deter Atrocity?' International Organization 70 (2016), 443. However, it also must be noted that that Jo and Simmons do not find that ratification itself decreases rebel-instigated violence against civilians. The reason is, they argue, that rebel groups are not the ones that commit to the Rome Statute. Ratification simply is not enough to alter the political strategy of non-state groups that use lethal violence to assert control in conflict zones.
}

${ }^{58}$ B.J. Appel 'In the Shadow of the International Criminal Court: Does the ICC Deter Human Rights Violations?' Journal of Conflict Resolution 62(1) (2018), 3.

${ }^{59}$ By using statistical modelling and anecdotal evidence Appel has shown that although governments with better human rights records are more likely to ratify the Rome Statute, their human rights practices still improve after ratification. The practices of nonratifiers, however, change very little across time. This suggests that the ICC appears to be associated with an independent effect on ratifiers that cannot entirely be explained by prior human rights practices, trends across time, or domestic conditions.

${ }^{60}$ J. Ku, J. Nzelibe 'Do International Criminal Tribunals Deter or Exacerbate Humanitarian Atrocities?' Washington University Law Review 84(4) (2006), 777; Y.M. Dutton and T. Alleblas 'Unpacking the deterrent effect of the international criminal court: Lessons from Kenya' St. John's Law Review 91(1) (2017) 105; M. Nalepa and E.J. Powell 'The Role of Domestic Opposition and International Justice Regimes in Peaceful Transitions of Power' Journal of Conflict Resolution 60(7) (2016), 1191. Dutton (2017) using the case study of Kenya, for example, argues that ICC Statute ratification, the lowest level of ICC intervention, did not prevent incidences of mass atrocities or other human rights abuses. Nalepa and Powell (2016) found that ICC ratification prolongs some dictatorial regimes. According to their study, a strong regional ICC presence decreases the likelihood that culpable dictators peacefully resign from power when the opposition has also committed atrocities. 
engage less in human rights abuses, which can amount to mass atrocity crimes, not only prior to, but perhaps more tellingly, after the ratification, and are more prone to end civil wars compared to their non-ratifying counterparts. In this respect, ratifying the ICC Statute by itself seems to further the aims of R2P. However, scholarship is much more mixed regarding effects of a more active ICC involvement in a situation of mass atrocities after the ratification of the Rome Statute, or in States, which have not acceded to the ICC treaty. For example, Dancy and Montal argue also on the basis of other existing empirical studies that across all countries that are subject to the ICC involvement, there has been no substantial decrease in violence against civilians. ${ }^{61} \mathrm{We}$ turn to these different modalities of the ICC involvement, which would fall under the pillar 2 and 3 of R2P, in the next sections.

\subsection{The Second Pillar: Complementarity, Preliminary Examinations and (Self-)referrals}

The second pillar encompasses the responsibility to help states to protect their own population. Several scholars note that the strength of the ICC actually lies not in its capacity to bring defendants in front of the Court, but in encouraging domestic prosecutions of these crimes. ${ }^{62}$ As the first ICC Prosecutor, Louis Moreno-Ocampo, famously noted "the number of cases that reach the Court, should not be a measure of its efficiency. On the contrary, an absence of trials before this Court, as a consequence of the regular functioning of national institutions, would be a major success. ${ }^{\circ 3}$ Complementarity is at the heart of the Court's ability to spark domestic action and is especially powerful when states have the domestic capacity to prosecute individuals but decide against this course of action. As

${ }^{61}$ G. Dancy, F. Montal, supra note 49, p. 679. They however also note two exceptions to this general "trend": Uganda and Lybia, where ICC intervention "coincides with a significant decline in 'government sponsored civilian casualties" citing research of Courtney Hillebrecht 'The Deterrent Effects of the International Criminal Court: Evidence from Libya' INT'L INTERACTIONS 42(2016), 616, p. 632 .

${ }^{62}$ K. Ainley, supra note 1, p. 48; A.M. Slaughter, W. Burke-White, 'The Future of International Law is Domestic (or, The European Way of Law)' Harv. Int'l L. J. 47(2) (2006), 327; W.W. Burke-White, 'Proactive Complementarity: The International Criminal Court and National Courts in the Rome System of International Justice' Harv. Int'l L. J. (2008b), 53.

${ }^{63}$ Cited in K.A. Marshall 'Prevention and Complementarity in the International Criminal Court: A positive Approach' Human Rights Brief 17(2) (2010) 21, p. 3. 
Slaughter and Burke-White explain "[t]he political benefits of adjudicating matters domestically rather than giving jurisdiction to an international tribunal over which domestic officials have little or no control creates new incentives to act locally." ${ }^{64}$ It is likely these incentives become greater when the Court actually takes steps to intervene by opening up a preliminary examination.

Where states struggle to find the resources to prosecute, the Court tries to facilitate the process; an approach the Court has referred to as positive or proactive complementarity. ${ }^{65}$ Positive complementarity dates back to 2003 and was further developed at the first Review Conference in 2010 which culminated in a resolution that detailed its scope. The overarching goal is to build national capacity through collaborative efforts of NGO's, IO's, states and the ICC. ${ }^{66}$ The ICC Prosecutor has committed itself to positive complementarity by stating in its 2009-2012 report:

the Office will encourage genuine national proceedings where possible, including in situation countries, relying on its various networks of cooperation, but without involving the Office directly in capacity building or financial or technical assistance. ${ }^{67}$

In its latest Strategic Plan 2016-2018, the OTP once more highlighted it aimed to contribute to positive complementarity without engaging directly in development aid. According to the report:

\footnotetext{
${ }^{64}$ A.M. Slaughter, W. Burke-White, supra note 62, p. 341.

${ }^{65}$ There is some debate as to how these variations of complementarity should be called. Some scholars will make a two-fold distinction between a "negative" or "passive" form of complementarity and a "positive" or "proactive" form of complementarity. Other scholars, like Imoedemhe, consider a threefold distinction of different forms of complementarity which includes "proactive complementarity" as a separate category. In the latter differentiation, positive complementarity entails actively motivating states to initiate prosecutions, while proactive complementarity facilitates building national capacity to prosecute (O.C. Imoedemhe The Complementarity Regime of the International Criminal Court: National Implementation in Africa (Cham: Springer, 2017), p. 47). Since the distinction between the latter two categories is often muddled (e.g. see Burke-White (supra note, 62, p. 56) who sees encouraging states as proactive complementarity as well), this article will use the two-fold distinction.

${ }^{66}$ E. Hunter, supra note 49, p. 30.

${ }^{67}$ ICC, 'Prosecutorial Strategy 2009-2012' (2010). Accessed 19 July 2019, https:// www.icc-cpi.int/NR/rdonlyres/66A8DCDC-3650-4514-AA62-D229D1128F65/ 281506/OTPProsecutorialStrategy20092013.pdf, p. 5.
} 
the Office's position is that it will not act as a development agency towards situations under preliminary examination or under investigation but that it can contribute to complementarity through the normal execution of its mandate, including through (1) the sharing of its expertise in international criminal law, investigations or witness protection upon request, (2) the inclusion, where appropriate, of national investigators or prosecutors into its teams for the duration of an investigation, or, (3) the participation in the coordination of national and ICC investigations. ${ }^{68}$

Several scholars see the potential of international courts and tribunals, and the ICC more specifically, in enhancing local justice capabilities. ${ }^{69}$ Stromseth in this respect argues that in order to do this, the international criminal courts need to understand the country in which they operate better, provide more effective outreach to demonstrate, and build confidence in, fair and impartial trials and be more proactive about capacity building. ${ }^{70}$

When the state truly deems itself unable to prosecute, it may also refer its own situation to the ICC. According to article 14 of the Rome Statute, a member state may refer a situation to the court. When the provision was drafted, it seems unlikely anyone had foreseen that it would have resulted in self-referrals. ${ }^{71}$ Nevertheless, four states have referred situations in their own country to the ICC and the Central African Republic decided to do so twice.

The next few paragraphs will discuss the various roles the ICC may play in the second pillar of R2P, starting with the least coercive one, positive complementarity. It subsequently discusses preliminary examinations where the domestic state remains in control but is pressured by the ICC to engage in domestic prosecutions. This section ends with a discussion of investigations following a referral of a situation to the Court by the domestic state.

${ }^{68}$ ICC, 'Strategic Plan, 2016-2018' (2015). Accessed 19 July 2019, https://www. icc-cpi.int/iccdocs/otp/EN-OTP_Strategic_Plan_2016-2018.pdf, p. 22.

${ }^{69}$ K.A. Marshall, supra note 63; J.E. Stromseth 'The International Criminal Court and Justice on the Ground' Arizona State Law Journal 43 (2011) 427, p. 429.

${ }^{70}$ Ibid., pp. 432-433; 443.

${ }^{71}$ P. Akhavan 'International criminal justice in the era of failed states: The ICC and the self-referral debate' in C. Stahn and M. El Zeidy (Eds.), The International Criminal Court and Complementarity: From Theory to Practice (Cambridge: Cambridge University Press, 2014), 283, p. 286. 


\subsubsection{Positive Complementarity}

Positive or proactive complementarity encompasses efforts by the ICC, in collaboration with other organizations, to help states with weak judicial systems to be able to live up to their obligation to prosecute perpetrators of atrocity crimes. ${ }^{72}$ The ICC, however, does not directly engage in capacity building. ${ }^{73}$ It should be clear, therefore, that beyond leading by example, the extent to which the ICC can really contribute to capacity building is very limited. In comparison to other tribunals, the challenges the ICC faces in the promotion of domestic judicial reform that would ease the prosecution of atrocity crimes may be bigger. ${ }^{74}$ Hybrid tribunals in particular will, for instance, train local legal practitioners and in doing so, will ultimately strengthen the domestic justice system in the long term. ${ }^{75}$ The ICC, as a permanent court, located in The Hague, is not able to contribute to the development of the domestic legal system in a similar vein.

What the Court can perhaps do is to engage more actively with other international institutions, NGO's, and State Parties to further expand the reach of international criminal justice. ${ }^{76}$ It can, for instance, focus the attention of NGO's by drawing attention to the most serious situations that are deserving of more international attention. As such, it can be influential in setting the agenda and be an important actor to draw resources to those conflicts without depleting its own limited budget. ${ }^{77}$ In this manner, the Court can ensure, in line with the idea of positive complementarity, that the domestic legal capabilities of the state are strengthened.

The most tangible result of the ICC's efforts to implement a policy based on positive complementarity has been the ICC Legal Tools Project. Through the project legal knowledge is disseminated on-line. Bergsmo et al. argue that the Legal Tools have value for different audiences. Not only can it be a very important resource of existing jurisprudence and legislation on international crimes from around the

\footnotetext{
${ }^{72}$ D. Saxon, supra note 47, pp. 137-138.

${ }^{73}$ J. Tillier 'The ICC Prosecutor and Positive Complementarity: Strengthening the Rule of Law?' International Criminal Law Review 13 (2013) 507, p. 509.

${ }^{74}$ W.W. Burke-White 'Implementing a Policy of Positive Complementarity in the Rome System of Justice' Criminal Law Forum 19 (2008a) 59, p. 76.

75 J.E. Stromseth, supra note 69, p. 437.

${ }^{76}$ K.A. Marshall, supra note 63, p. 1.

${ }^{77}$ K.A. Marshall, supra note 63, p. 4; W.W. Burke-White, supra note 74, p. 80.
} 
globe for states that want to exercise jurisdiction ${ }^{78}$ over international crimes, but it may also be used by other states, NGOs or international organization to pressure states to fulfil their obligations under the Rome Statute. ${ }^{79}$ The Legal Tools can inform states and NGOs, allowing them to built sound legal arguments that the human rights violations in a particular situation amount to international crimes and should be prosecuted as such, or can facilitate domestic prosecutions either in the state in which the crimes occurred, or by third states who wish to exercise universal jurisdication. According to Bergsmo et al., "providing effective access to legal information on war crimes, crimes against humanity and genocide is therefore one of the first steps in all capacity building in criminal justice for such crimes." 80

The extent to which an emphasis on positive complementarity is desirable for the ICC remains subject to debate. Scholars in favour of focussing more extensively on this particular aspect argue it is the most effective way to end impunity ${ }^{81}$ and some believe it can enhance the ICC's legitimacy. ${ }^{82}$ Others are more skeptical. Sekhon, for instance, finds the ICC is ill-equiped to implement a policy of positive complementarity and that it will be unable to do so in a neutral and apolitical manner. ${ }^{83}$ Phil Clark for example demonstrates that in the Democratic Republic of Congo and Uganda ${ }^{84}$ the ICC has in effect weakened domestic judicial reforms and practices aimed at combating mass atrocity crimes. Despite the fact that the ICC did play, according to Clark, a (minor) role in catalyzing legal reforms, its positive complementarity role has been greatly compromised by the Court's competitiveness with domestic courts and its tendency to usurp jurisdiction over cases that could have been handled domesti-

${ }^{78}$ The tool has been used in Bosnia-Hercegovina and the DRC (E. Hunter, supra note 49 , p. 31).

${ }^{79}$ M. Bergsmo, O. Bekou, A. Jones 'Complementarity After Kampala: Capacity Building and the ICC's Legal Tools' Groningen Journal of International Law 2 (2010), 791, p. 807.

${ }^{80}$ Ibid., p. 806.

${ }^{81}$ W.W. Burke-White, supra note 74.

${ }^{82}$ K. Ainley, supra note 1, p. 49.

${ }^{83}$ N. Sekhon 'Complementarity and Post-Coloniality' Emory International Law Review, 27 (2013), 799, p. 804.

${ }^{84}$ It should be noted, however, that in both cases the governments referred the situation of mass atrocity crimes on their territory to the Court, and the ICC started investigations, and trials. 
cally. ${ }^{85}$ As such, the ICC was used by the Ugandan, and especially the Congolese government to undermine domestic judiciaries, that have attempted a more difficult judicial task, namely pursuing the most serious charges - including murder and rape - against suspects, including government actors, which the ICC has avoided for the reasons of its heavy reliance on government cooperation. ${ }^{86}$

There are, therefore, some indications that the ICC can have a, very limited, influence on domestic capacity building. However, similar to our discussion of the ratification of the Rome Statute above, it is not a given that the capacity will be used by the state to prosecute perpetrators of international crimes - or states may do so selectively. In addition, even if the states were to pursue prosecutions, it is unclear whether this would facilitate the protection of populations because the extent to which prosecutions will deter the further commission of crimes continues to be highly debated. ${ }^{87}$

\subsubsection{Complementarity with a Preliminary Examination: State Still in Control}

The preliminary examination stage may be the result of a proprio motu decision (see also Section 4.3.3), a self-referral (see also Section 4.2.3), a referral by other states (see also Section 4.3.2) or may follow a UNSC referral (see also Section 4.4). The preliminary examination stage, in essence is not very threatening to the sense of autonomy of the domestic state. Preliminary examinations may allow the court to firstly, send missions to states where a preliminary examination is ongoing. Secondly, the Court in return may host delegations from such states in The Hague that frequently include representatives from government, the high court, opposition leaders and NGOs. Thirdly, the ICC can advise the state on measures that are to be taken. Fourthly, the Court may engage with the UN and other stakeholders to develop a prevention strategy. Fifthly, starting a preliminary examination allows the Court to disseminate infor-

${ }^{85}$ P. Clark Distant Justice, The Impact of the International Criminal Court on African Politics (Cambridge: Cambridge University Press, 2018), p. 152.

${ }^{86}$ Ibid., p. 167.

${ }^{87}$ H. Jo, B.A. Simmons, supra note 57; J. Ku, J. Nzelibe, supra note 60; M. Nalepa and E.J. Powell, supra note 60; C.W. Mullins and D.L. Rothe 'The Ability of the International Criminal Court to Deter Violations of International Criminal Law: A Theoretical Assessment' International Criminal Law Review 10 (2010), 771. 
mation to domestic as well as international audiences and finally, during this phase the Court will communicate relevant developments to the media and may report on the extent of cooperation in the country. ${ }^{88}$ However, this phase also signals the ICC may become involved and this may mean significant political costs for the states involved. As such it can potentially influence the policy of the state as well as the conflict dynamics. However, Dancy and Montal for example, computed that in contrast to largely positive impacts of the ICC Statute ratification (discussed above), there seems to be no statistically significant correlation between the ICC involvement (including not only preliminary examination, but also other actions of the Court, such as investigations and arrest warrants) and the end of fighting in ongoing wars. Furthermore, the ICC involvement does not appear to be associated with longer or shorter fighting. ${ }^{89}$ Additionally, the fact that peace negotiations are undertaken 'in the shadow of the ICC,' such as in Colombia, might prolong the actual negotiation process aimed to end fighting and mass atrocity crimes, as States need to keep their primary responsibility to prosecute crimes under the ICC Statute in mind when negotiating peace settlement of an armed conflict. In such situations, the ICC might more or less subtly push States to implement accountability mechanism for atrocity crimes in accordance to the ICC Statute, which can potentially hinder a negotiated settlement. Ultimately, this might for example contribute to excluding amnesties for mass atrocity crimes as a negotiated solution to ending the conflict and to agreeing on a creative, restorative punishment for these violations, as happened in the Colombia. $^{90}$

The extent to which the ICC influence is a positive one when it comes to protecting populations from atrocity crimes is, therefore, again subject to debate. According to Fatou Bensouda "the mere initiation of a preliminary examination has a deterrent effect." ${ }^{\text {"91 }}$ al-

${ }^{88}$ M. Holvoet, M. Mema 'The International Criminal Court and the Responsibility to Protect' in: D. Fiott, J. Koops, (Eds.) The Responsibility to Protect and the Third Pillar: Legitimacy and Operationalization (New York: Palgrave Macmillan, 2015), 21, p. 25.

${ }^{89}$ G. Dancy, F. Montal, supra note 49, p. 670.

${ }^{90}$ L. Rueda Guzman, B. Hola 'Punishment in Negotiated Transitions: The Case of the Colombian Peace Agreement with the FARC-EP' International Criminal Law Review 19(1) (2019) 127. It is, however, still being debated whether alternative sanctions, as currently being implemented in Colombia by the Special Jurisdiction for Peace, are in accordance to the ICC Statute.

${ }^{91}$ Cited in D. Saxon, supra note 47, p. 133. 
though the OTP Strategic Plan (2016-2018) stated more humbly that preliminary examinations "can [...] help deter actual or would-be perpetrators of atrocity crimes through the threat of international prosecutions." 92 Olassolo is likewise optimistic about its potential and argues that the preliminary examination in Afghanistan had a preventative effect with NATO changing their airstrike policy. ${ }^{93} \mathrm{It}$ has furthermore been suggested that the ICC can further the responsibility to protect by providing an incentive for the state to prosecute through complementarity. ${ }^{94}$ This implies assuming that prosecutions actually help to protect and while the UN, as explained above, seems to be quite convinced it will, scholars are much more divided.

In addition, it remains difficult to link domestic prosecutions and judicial reforms directly to the impact of the ICC. While there is some evidence that it may make some states more willing to prosecute, ${ }^{95}$ it seems that often prosecutions are quickly promised and more difficult to realise, as the situation in Guinea shows where 10 years after atrocities occurred the investigation by domestic authorities is finally completed but trials are still to start. ${ }^{96}$

The extent to which the domestic state acquiesced to be subjected to a preliminary examination will differ. This will be different for a self-referral as opposed to a proprio motu decision, a referral by other states or a UNSC resolution. Obviously with a self-referral this was the intended result while with a UNSC resolution referral, the state never even intended to be subjected to the Court's jurisdiction. This raises important questions in relation to the concept of consent and the second pillar of R2P. While a state consented to be subjected to the jurisdiction of the Court, by ratifying the Rome Statute, it never consented to the preliminary examination being opened up specifi-

\footnotetext{
${ }^{92}$ ICC, supra note 68, p. 21 (emphasis added).

${ }^{93}$ H. Olasoso The Role of the International Criminal Court in Preventing Atrocity Crimes Through Timely Intervention: From the Humanitarian Intervention Doctrine and Ex Post Facto Judicial Institutions to the Notion of Responsibility to Protect and the Preventative Role of the International Criminal Court. Utrecht: Willem Pompe Institute for Criminal Law and Criminology, Utrecht University, p. 7.

${ }^{94}$ D. Saxon, supra note 47 , pp. $158-159$.

${ }^{95}$ K. Ainley, supra note 1, p. 48.

${ }^{96}$ Cited in D. Saxon, supra note 47, pp. 152-153; progress continues to be made, however, see ICC Report on Preliminary Examination Activities 2018 (2018). Accessed 19 July 2019, https://www.icc-cpi.int/itemsDocuments/181205-rep-otp-PEENG.pdf, p. 48.
} 
cally, raising the question whether preliminary examinations still belong within the second pillar. To what extent can the ICC, without actually intervening against the wishes of the state, provide incentives that will help and motivate states to implement policies that may eventually have a protective effect? Since the source of these incentives is the threat that if states do not sufficiently prosecute international crimes domestically, the Court will intervene, a debate needs to be had on the limits of this consent. When does this threat become so coercive that the actions of the Court move from the second to the third pillar?

\subsubsection{An Investigation after a Self-referral: When the State Decides to Relinquish Control}

When the Rome Statute was negotiated nobody envisioned that states would opt to refer situations in their own country to the Court. When Uganda decided to use article 14 of the ICC Statute to refer its own situation to the Court, debate arose as to the legality of "selfreferrals." "97 The Trial Chamber decided in the Katanga/Chui decision that self-referrals are permissible ${ }^{98}$ and so far, four states have deemed it necessary to make use of the provision. According to Akhavan, the self-referrals may serve as a "life-line" for fragile states. A self-referral to the ICC may be a valuable option for states when there is a volatile security situation, when trials may be too costly or when the nation is divided and domestic prosecutions are no longer credible. ${ }^{99}$ The OTP has also actively encouraged states to make use of this provision, expecting to receive genuine cooperation from the domestic state in these instances. ${ }^{100}$ As Clark demonstrates, it is for example questionable whether self referrals in both, Uganda and the Democratice Republic of the Congo (DRC), can be considered 'voluntary'.

\footnotetext{
${ }^{97}$ P. Akhavan, supra note 71, pp. 284-5.

98 The Prosecutor v. Germain Katanga and Mathieu Ngudjolo Chui 'reasons for the Oral Decision on the Motion Challenging the Admissibility of the Case (Article 19 of the Statute)' ICC-01/04-01/07 para 80.

${ }^{99}$ P. Akhavan, supra note 71.

100 J. Tillier, supra note 73, pp. 521-2; P. Gaeta 'Is the Practice of 'Self-Referrals' a Sound Start for the ICC?' Journal of International Criminal Justice, 2 (2004), 949, p. 950.
} 
Rather than these states referring their situations voluntarily to the ICC, as Court officials consistently claim, the OTP initiated negotiations with the Ugandan and Congolese governments before the referrals took place. Having chased these state referrals, the ICC was forced to negotiate the terms of its investigations with those governments. ${ }^{101}$

In some cases, the ICC issued thinly veiled threats of using its propio motu powers if the state did not refer the situation themselves. A year before the DRC referred its own situation to the court, for instance, the Prosecutor said in a speech at the Second Assembly of State Parties:

In particular, I hope the national system can be reinvigorated with the assistance from the international community in order to enable the Congolese themselves to investigate and prosecute those responsible. If necessary, however, I stand ready to seek authorization from a Pre-Trial Chamber to start an investigation under my proprio motu powers [...] Our role could be facilitated by a referral or active support from the DRC. ${ }^{102}$

The prosecutor therefore seemed to want to force the hand of the $\mathrm{DRC}$, to either start prosecuting, or allow the ICC to do so on their behest. Even when the country opts for the latter option, however, other fractions in the government might still want to reform the domestic judiciary to stave off ICC involvement, as was the case in the DRC. ${ }^{103}$

Ideally, self referrals would allow states that are confronted with situations of mass atrocities to refer their situation to the Court when they feel incapable of prosecuting the perpetrators themselves. To the extent that such accountability measures may work to incapacitate those responsible for mass atrocities, and potentially through its symbolic value, the Court could potentially play a role in the implementation of $\mathrm{R} 2 \mathrm{P}$. In practice, however, the states do not necessarily make the decision to refer their situation to the ICC because they want to prevent the recurrence of the crimes. Rather, the decision to refer a case to the Court can be a politically opportune one, that allows the government to gain advantage over its political opponents. ${ }^{104}$ This was also the case in the DRC and Uganda, where

${ }^{101}$ P. Clark, supra note 85, p. 55.

102 Cited in J. Tillier, supra note 73, p. 525.

${ }^{103}$ W.W. Burke-White, 'Complementarity in Practice: The International Criminal Court as Part of a System of Multi-level Global Governance in the Democratic Republic of Congo' Leiden Journal of International Law 18 (2005), 557.

${ }^{104}$ W.W. Burke-White, supra note 103, p. 565; A. Tiemessen supra note 37, p. 454. 
accountability has been criticised as being "selective and partial [and] in favour of ruling elites within the government and military" and the country has only selectively, depending on their own interests, cooperated with the Court. ${ }^{105}$ Additionally, Clark argues, that such "selective cooperation with the ICC was used as a legitimation tool" by the DRC and Ugandan governments, and allowed to portray themselves as dedicated to the rule of law and international accountability, while simultaneously cracking down violently dissident voices at home. ${ }^{106}$

As such, the possibility to refer a situation to the Court has become a way for the court to help states combat impunity. At the same time, however, domestic elites have used the possibility to refer their situation to the court to target political opponents and have used the Court to cater to their political interests. Additionally, even if the Court "stays in line" and targets only the opposition forces, its impact on the ground still seems to be quite uncertain. For example, Broache shows mixed effects of the ICC actions on M23 group violence in Congo. The publication of an arrest warrant in April 2008 for Bosco Ntaganda had negligible effects. However, the announcement of the conviction of Thomas Lubanga and associated calls for Ntaganda's arrest in March 2012 led to an escalation of atrocities, while Ntaganda's surrender in March 2013 contributed to prevention, and decrease of violence by undermining M23's capacity. So even in this scenario, ICC action can alternately prevent, exacerbate or have no impact on atrocities, depending on concrete circumstances on the ground. ${ }^{107}$

In this respect, self-referrals are likely to have an uncertain impact on the protection of the population given the selectivity that seems to be inherent in those proceedings and the fluid impact the Court's actions have on the ground, depending on local cricumstances. Especially when used because they are politically expedient for political elites, self-referrals do not ensure cooperation for the duration of the legal proceedings and even when the involvement of the ICC is no longer deemed convenient for domestic elites, the Court will continue to investigate and prosecute, as was the case in Uganda. While initially the Court's involvement served Museveni's interests, in later years he became a fervent opponent and cooperation became

\footnotetext{
105 A. Tiemessen, supra note 37, p. 452; P. Clark, supra note 85 , p. 82.

106 P. Clark, supra note 85 , p. 86.

${ }^{107}$ M. Broache 'International prosecutions and atrocities in the Democratic Republic of the Congo: A case study of the FDLR' The Journal of the Middle East and Africa 7(1) (2016) 19.
} 
more moderate. ${ }^{108}$ Such varying degrees of cooperation complicate the Court's involvement as a tool in the second pillar as will be explained further below. ${ }^{109}$

\subsection{Pillar Two and a Half: Beyond the Consent of the State}

There will be instances where, even when the state voluntarily acquiesced to ICC involvement, actions of the Court will go directly against the preferences of the state at that moment. In those situations, the involvement of the Court extends beyond the "encouragement" or "help" which the second pillar speaks of. Yet, the third pillar of R2P restricts the involvement of the international community to that which goes through the UN Security Council. In essence, therefore, there is a grey area; a pillar two and a half.

\subsubsection{The Court Goes Beyond the Country Consent of the State After a Self-referral}

While in general, states who have referred their own situation to the ICC are more cooperative, ${ }^{110}$ cooperation may vary over time. Even when the state originally consented, even requested the involvement of the ICC, it may oppose some of its decisions. The Ugandan government, for instance, has threatened to stop cooperating with the Court if anyone from the government or the military is indicted. ${ }^{111}$ Similarly, within the DRC cooperation has been based on political expediency, which, as Tiemessen argues, became particularly clear in the Ntaganda case. Ntaganda was protected by the government until he defected in 2012 and eventually requested to be handed over to the ICC. ${ }^{112}$ Therefore, in the realm of possibility, as this has not happened as of yet, the Court theoretically could 'overstep' an initial governmental consent, and enforce accountability also for actors and atrocities not envisaged in the initial referral. When the state opposes actions of the Court, intervention by the Court moves away from the second pillar and starts to fit uncomfortably in the R2P pillar structure.

${ }^{108}$ C. Hillebrecht and S. Strauss 'Who Pursues the Perpetrators? State Cooperation with the ICC' Human Rights Quarterly 39(1) (2017) 162, pp. 177-178.

109 See Section 4.3.1.

${ }^{110}$ C. Hillebrecht and S. Strauss, supra note 108, p. 163.

111 A. Tiemessen, supra note 37, p. 451.

${ }^{112}$ Ibid., p. 452. 


\subsubsection{Investigations After Referral by Other States}

A similar situation arises when the ICC initiates investigations after a referral of a situation by other states. The state in question needed to have ratified the Rome Statute in the first place, so in broad manners acquiesced to the ICC jurisdiction, and during preliminary examinations still theoretically retains an amount of control over the situation. It could potentially act itself, and demonstrate that it is willing and able to prosecute perpetrators of atrocity crimes. This "control over the situation" is lost when the ICC assesses the state as unable or unwilling to genuinely do so in accordance with article 17 of the Rome Statute and initiates an investigation. In such a scenario, the ICC investigations arguably go against the preferences of the concerned state (as it did not self-refer nor initiated genuine criminal prosecutions itself). For example, on 27 September 2018, Argentina, Canada, Colombia, Chile, Paraguay and Peru, referred the situation in Venezuela to the Court. It was a somewhat surprising move because the situation already had been under preliminary examination since February 2018, which was initiated through a proprio motu by the ICC Prosecutor. ${ }^{113}$ In a press release statement Bensouda explains that the preliminary examination "will continue to follow its normal course" and legally the only implication seems to be that now the Prosecutor does not need authorisation from the Pre-Trial Chamber to proceed to open an investigation. ${ }^{114}$ Some have, therefore, argued that the referral was mainly a political move, meant to signal the support of the referring countries for an investigation of the ICC into the situation in Venezuela. ${ }^{115}$ In any case, the Venezuelan referral was the first time in the history of the ICC that other states referred a situation of atrocities on a territory of another State Party to the Court. The impact and consequences of potential ICC investigations on the protection of populations and $\mathrm{R} 2 \mathrm{P}$ in general in such a scenario, if ever initiated, therefore, remain to be seen.

${ }^{113}$ ICC 'Statement of the Prosecutor of the International Criminal Court, Fatou Bensouda, on opening Preliminary Examinations into the situations in the Philippines and in Venezuela' (2018). Accessed 19 July 2019, https://www.icc-cpi.int/Pages/ item.aspx?name $=180208$-otp-stat See also Section 4.3.3.

${ }^{114}$ ICC 'Statement of the Prosecutor of the International Criminal Court, Fatou Bensouda, on the referral by a group of six States Parties regarding the situation in Venezuela' (2018), accessed 19 July 2019, https://www.icc-cpi.int/Pages/item.as px?name $=180927$-otp-stat-venezuela.

115 N.E. Ortiz 'Understanding the State Party Referral of the Situation in Venezuela' EJIL:Talk! (2018) Accessed 19 July 2019, https://www.ejiltalk.org/under standing-the-state-party-referral-of-the-situation-in-venezuela/. 


\subsubsection{Proprio Motu Decisions and Investigations}

When the ICC initiates proceedings under the proprio motu powers of the OTP, the state itself will have accepted the jurisdiction of the Court, since it ratified the Rome Statute, but it will not necessarily welcome the Court's involvement in a particular situation. The situation in Kenya is a case in point. After the post-election violence in 2008, the Kenyan Commission of Inquiry into Post-Election Violence (CIPEV - the Waki Commission) was established. It recommended the establishment of Special Tribunal of Kenya to prosecute the crimes and threatened that if such a tribunal would not be established, a list of names with those most responsible for the violence would be sent to the ICC. ${ }^{116}$ While the government promised accountability, the promises remained unfulfilled and in 2010, Moreno Ocampo decided to investigate the situation. Kenyatta and Ruto, who were both indicted for their involvement in the 2008 violence, won the subsequent presidential poll in March 2013 and have been resisting ICC involvement. They found an ally in the African Union and their position was endorsed with a Resolution that was brought before the UN Security Council to defer the situation before the ICC in accordance with article 16 of the Rome Statute. ${ }^{117}$ Similar to the mixed impact of ICC investigations on protection of civilians after the self-referral in Congo noted above, Dutton and Alleblas argue that the impact of the ICC in Kenya on protection of civilians varied and that this case demonstrated the varying positive and negative effects on the ground depending on the particular political context at the particular point of time of the ICC actions, the type of actor the ICC pursues, and based on how strongly and well the ICC exercises its institutional powers. ${ }^{118}$

Additionally, as the situation in Afghanistan demonstrates, a proprio motu investigation might also have repercussions for states that did not ratify the Rome Statute. After conducting its preliminary examination, the Prosecutor concluded that there was a reasonable basis to believe crimes within the jurisdiction of the Court had been committed in Afghanistan by members of the Taliban and affiliated groups, by members of the Afghan National Security Forces and by members of the US Armed Forces and the Central Intelligence

${ }^{116}$ T. Murithi 'Ensuring Peace and Reconciliation while Holding Leaders Accountable: The Politics of ICC Cases in Kenya and Sudan' Africa Development XL2 (2015), 73, p. 79.

117 T. Murithi, supra note 116, pp. 82-85; A. Tiemessen, supra note 37, p. 457.

${ }^{118}$ Dutton and Alleblas, supra note 60. 
Agency. ${ }^{119}$ Throughout the preliminary investigation, the US had been largely uncooperative and increasingly more and more openly hostile to the Court. In April 2019, the US government even revoked the Prosecutor's visa to travel to the country. ${ }^{120}$ For the Pre-Trial Chamber, the uncooperative stance of the US, and potentially other states, was one of the reasons to determine that an investigation in Afghanistan would not serve the interest of justice. ${ }^{121}$ The decision was heavily criticised ${ }^{122}$ for being self-defeating in the goals it wishes to achieve; ending impunity and preventing mass atrocities. ${ }^{123}$ When states know that an uncooperative stance can potentially keep the court's involvement at bay, this can negatively impact any deterrent or preventative effect the Court could otherwise have. Goh even goes so far to argue that "the decision not to authorise an investigation on the basis of lack of state cooperation ... not only excuses such behaviour but encourages such behaviour" (emphasis in original). ${ }^{124}$

${ }^{119}$ L. Poltronieri Rossetti ‘The Pre-Trial Chamber's Afghanistan Decision: A Step Too Far in the Judicial Review if Prosecutorial Discretion?' Journal of International Criminal Justice 17 (2019), 585; Public redacted version of "Request for authorisation of an investigation pursuant to article 15", 20 November 2017, ICC-02/17-7Conf-Exp (2017) Accessed 5 April 2020, https://www.icc-cpi.int/CourtRecords/ CR2017_06891.PDF.

${ }^{120}$ S.C. Goh 'Afghanistan: Towards Wider Interests of Justice?' LSE Law Review 5 (2020), 49, p. 52; BBC 'US revokes Visa of International Criminal Court Prosecutor' (2019) Accessed 5 April 2010, https://www.bbc.com/news/world-us-canada47822839 .

${ }^{121}$ Decision Pursuant to Article 15 of the Rome Statute on the Authorisation of an Investigation into the Situation in the Islamic Republic of Afghanistan No (2019) Accessed 5 April 2020, https://www.icc-cpi.int/CourtRecords/CR2019_02068.PDF.

122 Poltronieri Rossetti, supra note 119; Goh, supra note 120.

${ }^{123}$ These goals were explicitly repeated in the Pre-Trial's judgment when it indicated that "[f]rivolous, ungrounded or otherwise predictably inconclusive investigations would unnecessarily infringe on fundamental individual rights without serving either the interests of justice or any of the universal values underlying the Statute, as spelt out in the Statute's Preamble: ending impunity and preventing mass atrocities with a view to achieving peace, security and the well being of the people." Decision Puruant to Article 15 supra note 121, p. 12, para 34.

${ }^{124}$ Goh, supra note, 120, p. 53; see also K.J. Heller 'One Word for the PTC on the Interests of Justice: Taliban' Opinio Juris (2019) Accessed 9 April 2020, http://opi niojuris.org/2019/04/13/one-word-for-the-ptc-on-the-interests-of-justice-taliban; S. Vasiliev 'Not just another 'crisis': Could the blocking of the Afghanistan investigation spell the end of the ICC? (Part I)' EJIL:Talk! (2019) Accessed 9 April, https://www. ejiltalk.org/not-just-another-crisis-could-the-blocking-of-the-afghanistan-investigationspell-the-end-of-the-icc-part-i/; S. Vasiliev 'Not just another 'crisis': Could the blocking of the Afghanistan investigation spell the end of the ICC? (Part II)' EJIL:Talk! (2019) 
Recently, the ICC Appeals Chamber, however, overturned the decision, ${ }^{125}$ based on procedural grounds arguing that the Pre-Trial Chamber exceeded its jurisdiction in deciding on the "interest of justice," which is, according to the ICC Statute, a prerogative of the Prosecution. The judicial developments in the Afghanistan situation indicate that the Court's own interpretation of its role and functioning is perhaps not entirely settled yet. This can affect its potential impact on the protection of populations even in states that ratified the Statute and are generally supportive of the Court. Pursuant to the Appeals Chamber decision, the Prosecutor is now authorized to open an investigation in the Afghanistan situation, and potentially also target representatives of States that have not ratified the ICC Statute and are openly hostile to the Court. It remains to be seen what impact actions of the Court will have on the ground in such complex circumstances.

In sum, involvement of the ICC through the proprio motu powers of the OTP also fit poorly in the present pillar structure of R2P since it neither occurs with the consent of the state at that point in time, nor does it entail the involvement of the UN Security Council. Times change and countries can go through great lengths to oppose ICC involvement even when they once acquiesced to its jurisdiction by ratifying the Rome Statute. In addition, countries that never accepted the Court's jurisdiction through the Rome Statute might be impacted by its proceedings. These situations seem to be moving ever closer to pillar three due to the complete lack of state consent to be part of the Court's proceedings.

\subsection{The Third Pillar: UN Security Council Referrals}

By accepting the responsibility to protect, states indicated they were willing to intervene to protect populations elsewhere but the exact phrasing of R2P in the World Summit outcome document limits any intervention to that what is authorised by the UNSC. Despite the fact

\footnotetext{
Footnote 124 continued https://www.ejiltalk.org/not-just-another-crisis-could-the-blocking-of-the-afghanistan-investigation-spell-the-end-of-the-icc-part-ii/.

125 Judgment on the appeal against the decision on the authorisation of an investigation into the situation in the Islamic Republic of Afghanistan (2020) Accessed 5 April 2020, https://www.icc-cpi.int/CourtRecords/CR2020_00828.PDF.
} 
that a possibility of the UN Security Council to refer situations of atrocity crimes is envisaged in the ICC Statute (Art 13b), some argued that the possibility of a UN Security Council referral would never be used given the US' fierce opposition to the Court itself. ${ }^{126}$ However, the use of the ICC by the UNSC has superseded expectations. So far, it has decided to refer two situations to the Court and, according to Fehl, "policymakers have accorded criminal sanctions a prominent place in the non-military arsenal of the RtoP." 127

However, the role of the UNSC and the inconsistent manner in which the UNSC has used its power to refer situations to the Court, while not following through with assistance to actually try those indicted, has been subject to significant criticism. ${ }^{128}$ For the ICC, the inconsistency of the UNSC has meant its credibility has been questioned. Debates center around why the UNSC refers some, but not other situations, and the extent to which this causes the Court to focus too much on African situations. For R2P, too, the inconsistency with which the norm is evoked, in particular in relation to Libya but not Syria, has been troubling to many and led to debates on the future of R2P. ${ }^{129}$

The perceived hypocrisy of the UNSC has heightened the concerns that the UNSC may politicise the Court. Mills, for instance, argues the ICC should be separated from global politics as much as possible. ${ }^{130}$ Birdsall, in a similar vein, believes that the ICC does not have much to gain from its association with $\mathrm{R} 2 \mathrm{P}$ because it is not capable

${ }^{126}$ P. Gaeta, supra note 100, p. 951.

${ }^{127}$ Fehl, C. 'Probing the Responsibility to Protect's Civilian Dimension: What Can Non-Military Sanctions Achieve?' in D. Fiott and J. Koops (eds.) The Responsibility to Protect and the Third Pillar (London: Palgrave Macmillan, 2015) 39, p 48.

${ }^{128}$ T. Murithi, supra note 116, p. 92; A. Hehir and A. Lang, supra note 10; K. Bowman "The International Criminal Court and the Security Council: The Power of Politics and the Undermining of Justice" in: J. Nicholson (ed.) Strengthening the Validity of International Criminal Tribunals (Leiden, The Netherlands: Brill, 2018), 247.

${ }^{129}$ A. Hehir and A. Lang, supra note 10; T. Murithi, supra note 116, p. 92; J. Morris (2013) 'Libya and Syria: R2P and the spectre of the swinging pendulum' International Affairs 89(5) (2013) 1265; R. Thakur (2013) 'R2P after Libya and Syria: Engaging Emerging Powers' The Washington Quarterly 36(2) (2013), 61; S. Brockmeier, O. Stuenkel, M. Tourinho (2016). 'The Impact of the Libya Intervention Debates on Norms of Protection' Global Society 30(1) (2016), 113; D. Rieff, 'R2P, R.I.P.' The New York Times, (2011) Accessed 3 July 2019, https://www.nytimes.com/ 2011/11/08/opinion/r2p-rip.html.

${ }^{130}$ K. Mills, supra note 10, p. 91. 
of solving ongoing conflicts and it could risk becoming seen as a political tool. ${ }^{131}$ The concern of these, and other scholars, rests with the fact that the Court derives much of its, already questioned, legitimacy from its independence and that this would be harmed by a closer collaboration with the UNSC. ${ }^{132}$

At the same time, other scholars are also concerned that a close association with the ICC might be harmful to $\mathrm{R} 2 \mathrm{P}$ as an international norm because it could risk R2P becoming associated with regime change to the extent it is not already. ${ }^{133}$ In particular, the recent intervention in Libya, which was mandated by the UNSC under the R2P banner and included an ICC referral, has highlighted such fears. ${ }^{134}$ In addition, some contend that states who interve in a situation of mass atrocities, or rather their officials, may be subjected to ICC investigation, potentially reducing their willingness to act. ${ }^{135}$ The latter is, however, somewhat of an empty argument since there is no reason why intervening to protect populations should necessarily mean engaging in criminal conduct, and even if for example war crimes are committed within such intervention, under the Rome Statute states retain the primary responsibility to prosecute. Specifically, Holvoet and Mema point to the potential adverse consequences of the incorporation of the crime of aggression in the Rome Statute for R2P, which they argue potentially limits the willingness to intervene out of fear of being prosecuted by the ICC. ${ }^{136}$ This, however, neglects the fact that military intervention under the R2P banner requires UNSC authorisation, and therefore cannot be prosecuted as a crime of aggression.

While ICC involvement through the UNSC has been characterised by its ineffectiveness due to the obvious lack of cooperation of the targeted state and the inability of the Court to act in the absence of follow-up financial, material and symbolic support of the Council,

${ }^{131}$ A. Birdsall, supra note 40, p. 52.

${ }^{132}$ K. Ainley, supra note 1, p. 45.

133 J. Ralph, supra note 41, p. 3; N. McMillan and D. Mickler 'From Sudan to Syria: Locating 'Regime Change' in R2P and the ICC' Global Responsibility to Protect 5(3) (2013), 283.

${ }^{134}$ Although some argue that the extent to which R2P was used to legitimize the intervention in Libya has been overstated see J. Morris 'Libya and Syria: R2P and the spectre of the swinging pendulum' International Affairs 89(5) (2013) 1265; N. McMillan and D. Mickler, supra note, 131, p. 284.

${ }^{135}$ M. Holvoet, M. Mema, supra note 88, p. 22.

${ }^{136}$ Ibid. 
this does not mean that UNSC referrals to the Court are completely devoid of impact. Hillebrecht argues that in the case of Lybia, the ICC had an impact on actors on the ground and led to an improvement of their human rights practices, in particular when it comes to government sponsored civilian casualties.

The UN Security Council referral - a manifestation of the international community's willingness to support prosecution in a timely manner-prompted a significant abatement in the level of civilian casualties, while later [ICC] procedural actions, like issuing arrest warrants or invoking INTERPOL, have little, if any, statistically significant effect [on the number of civilian casualties]. ${ }^{137}$

After the UNSC referred the situation in Darfur to the ICC, the Sudanese government passed several reforms and created ad hoc institutions to demonstrate their willingness and capability to prosecute. ${ }^{138}$ According to Nouwen:

[p]ublicly, Sudan rejected the Security Council's referral and the Prosecutor's opening of an investigation into the situation in Darfur. President Bashir swore 'thrice in the name of Almighty God. never [to] hand any Sudanese national to a foreign court'. But, outside the view of the Sudanese gallery, the G[overnment o[f] S[udan] [GoS] extended some cooperation to the Court. On 2 October 2005, it signed an agreement with the ICC to cooperate with the Court in its case against the LRA. With respect to the Darfur situation, the GoS allowed five diplomatic ICC missions to visit Khartoum to assess questions of admissibility. It made some attempts to convince the OTP that Sudan has a functioning justice system. [...] All cooperation came to an abrupt end, however, when, nearly two years after the referral, the ICC Prosecutor applied for summonses to appear, or in the alternative warrants of arrest, for Ahmad Muhammad Harun and Ali Muhammed Abd-al-Rahman, also known as Ali Kush- ayb. ${ }^{139}$

In those instances, an indictment can also hinder the protection of civilians. Similar to Kenya, following the subsequent ICC indictment against the then Sudanese President Omar Al Bashir, Sudan attempted to influence "the Security Council to 'withdraw' the referral, suspend the ICC proceedings 'indefinitely' or 'cancel' the arrest

${ }^{137}$ C. Hillebrecht 'The Deterrent Effects of the International Criminal Court: Evidence from Libya' 42 INT'L INTERACTIONS 42(4) (2016) 616, p. 632.

${ }^{138}$ J. Tillier, supra note 73, pp. 517-518; S.M.H. Nouwen Complementarity in the Line of Fire: The Catalysing Effect of the International Criminal Court in Uganda and Sudan (Cambridge: Cambridge University Press, 2013).

139 Ibid., pp. 248-249. 
warrants." 140 In addition, Duursma and Müller argue that the indictment against Al-Bashir severely complicated the efforts of peacekeepers and humanitarian workers ${ }^{141}$ and as such ICC involvement may have hindered in the attempt to protect populations. Many scholars also feared that the involvement of the ICC may be detrimental to peace-processes and therefore, negatively affected the protection of civilians. On the other hand, in relation to Libya, Kersten, argues the ICC cannot be blamed for the failure of peace accords but at the same time notes the ICC was also not able to positively influence the prospects for peace and justice in the country. ${ }^{142}$

\section{THE FLUID NATURE OF THE INTERACTION: SHIFTING BETWEEN PILLARS}

With the increased emphasis on international criminal justice as a legitimate policy tool to combat mass atrocities since the end of the Cold War, it comes as no surprise that the ICC has been framed as a tool in the toolbox of R2P. However, the many options the ICC has at its disposal through which it can potentially play a role, for better or worse, in situations of mass atrocities to protect civilian populations, fit awkwardly in the pillar structure of R2P. States have for instance consented to the possibility of ICC involvement by ratifying the Rome Statute, but when the OTP decides to initiate investigations propio motu, the state may very well disapprove. In addition, when states decide to refer their own situation to the Court, there may be the initial wish for ICC involvement, or selective involvement against States' opponents, but there is no guarantee this will last throughout the proceedings especially when the ICC decides to cast a wider net than initially hoped for by the state, or in case there is a change in the political situation in the State, causing it to no longer be supportive of the Court. While the second pillar rests on the consent of the domestic state, the ICC's legal logic is likely to go further than is deemed desirable by the pragmatic domestic elite.

${ }^{140}$ Ibid., p. 253.

${ }^{141}$ A. Duursma and T.R. Müller 'The ICC indictment against Al-Bashir and its repercussions for peacekeeping and humanitarian operations in Darfur' Third World Quarterly, 40(5) (2019), 890; see also S.M.H. Nouwen, supra note 138, p. 275.

${ }^{142}$ M. Kersten Justice in Conflict: The Effects of the International Criminal Court's Interventions on Ending Wars and Building Peace (Oxford: Oxford University Press, 2016), pp. 16-17. 
To complicate matters further, governments may also make voluntary changes to their domestic legal system and or policies in response to potential interventions after a UNSC referral. An intervention by the Court, thus assisting in the implementation of pillar 3, may in effect cause the state to act on its own accord. The intervention may thus also "encourage" a state to act, in essence facilitating the implementation of the second pillar.

In addition, there are also unintended consequences of ICC interventions. Dancy and Montal for instance have found that investigations by the ICC may lead to more domestic prosecutions of human rights violations more generally. ${ }^{143}$ Although this falls outside of the scope of $\mathrm{R} 2 \mathrm{P}$ as such, systematic violations of human rights may at times forebode the perpetration of atrocities. ${ }^{144}$

Therefore, while there is a tendency, within the UN in particular, to analyse the options to protect populations along R2P's different pillars, the pillar structure is much more fluid than is reflected in the current debate on the topic. The academic debate that seems to focus predominantly on how the ICC and R2P influence each other, without paying any attention to the different roles the ICC can play in each of the pillars, obscures how uneasy some of the ICC's practices fit into the pillar structure and how in certain situations the Court can positively contribute to the protection of civilians, while in others it can stall or worsen the situation.

\section{CONCLUSION}

While the ICC has frequently been referred to as a tool in the R2P toolbox, the manner in which its activities fit into the three-pillar structure is not self-evident and the impact of its activities on the protection of civilians is largely mixed. The involvement of the Court in different situations will shift across the three pillars at different points in time and there seems to be a grey area between pillar two and three. When the Court makes a proprio motu decision to start a preliminary examination and subsequently initiates an investigation, or when the Court acts in a manner that extends beyond the wishes of the state after there was a self-referral, a pillar two-and-a-half needs

${ }^{143}$ G. Dancy, F. Montal, supra note 49.

${ }^{144}$ M. O'Brien 'Human Rights and Atrocity Crimes' in B. Hola, H. Nyseth Brehm, M. Weerdesteijn (eds) Oxford Handbook on Atrocity Crimes (New York: Oxford University Press, 2020, forthcoming), on file with the authors. 
to be conceptualised to accommodate the Court's work in R2P's three pillar structure.

Given the fact that currently, much of the scholarship sees consent of the state as a crucial element within the second pillar, an important question the present analysis raises is the point when encouragement, help and consent ends, and coercion begins when the Court undertakes efforts to end impunity for atrocity crimes in different mass atrocity situations. A state may be strong-armed through policies of positive complementarity by the Court in changing its domestic system. Several scholars have deemed this to be the Court's most promising feature and can be seen as implementing R2P's second pillar but it is important to realise that it stretches the terms encourage and help as developed in the WSOD.

In addition, the involvement of the Court may stem from a UNSC resolution, and fit seemingly neatly into the third pillar of $\mathrm{R} 2 \mathrm{P}$, but such an intervention may spark voluntary domestic reforms of the judicial sector and thus, in line with pillar two, encourage the state to act. Overall the workings of the Court create a fluid dynamic that shifts back and forth between the different pillars at different points in time and can contribute to different pillars at the same time but in some instances fits uncomfortably in the pillar structure, potentially necessitating the conceptualisation of a pillar two and a half.

\section{OPEN ACCESS}

This article is licensed under a Creative Commons Attribution 4.0 International License, which permits use, sharing, adaptation, distribution and reproduction in any medium or format, as long as you give appropriate credit to the original author(s) and the source, provide a link to the Creative Commons licence, and indicate if changes were made. The images or other third party material in this article are included in the article's Creative Commons licence, unless indicated otherwise in a credit line to the material. If material is not included in the article's Creative Commons licence and your intended use is not permitted by statutory regulation or exceeds the permitted 
use, you will need to obtain permission directly from the copyright holder. To view a copy of this licence, visit http://creativecommons.org/licenses/by/4.0/.

Publisher's Note Springer Nature remains neutral with regard to jurisdictional claims in published maps and institutional affiliations. 